\title{
The relation between pica and iron deficiency in children in Zanjan, Islamic Republic of Iran: a case- control study
}

Mansour Sadeghzadeh ${ }^{1}$ Parisa Khoshnevisasl ${ }^{2}$ and Sina Sadeghzadeh ${ }^{3}$

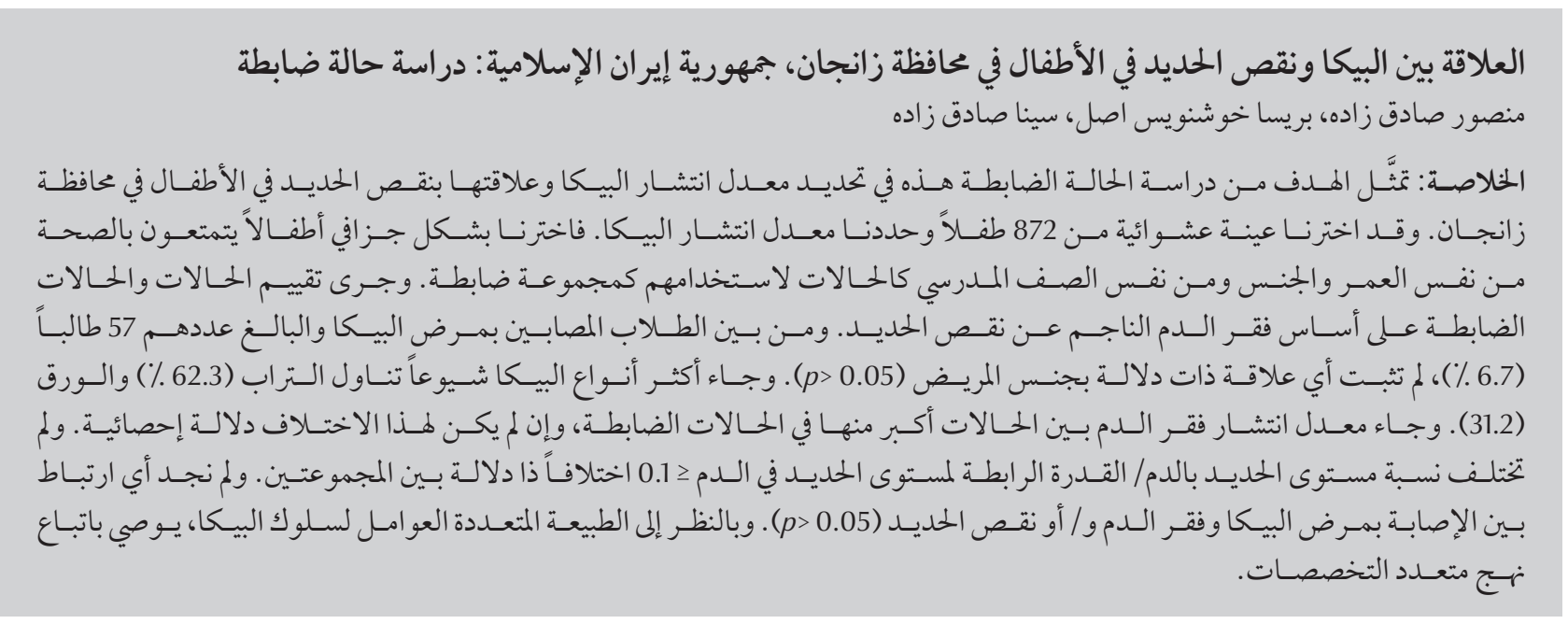

ABSTRACT The aim of this case-control study was to determine the frequency of pica and its relationship with iron deficiency in children in Zanjan. We selected 872 children and determined the frequency of pica. We selected students who did not have pica of the same age and sex, and in the same class as our cases as a control group. Both groups were evaluated for iron deficiency anaemia. Among the 57 students (6.7\%) who had pica, there was no significant relationship with sex $(P>0.05)$. The most common types of pica were soil $(62.3 \%)$ and paper $(31.2 \%)$. The frequency of anaemia among cases was greater than in controls, although the difference was not statistically significant. The serum iron/total iron binding capacity ratio $\leq 0.15$ did not differ significantly between the 2 groups. We did not find any association between pica and anaemia and/or iron deficiency $(P>0.05)$.

Lien entre le pica et les carences en fer chez les enfants à Zanjan, République islamique d'Iran : étude castémoin

RÉSUMÉ La présente étude cas-témoin avait pour objectif de déterminer la fréquence du pica et son lien avec les carences en fer chez les enfants de Zanjan. Nous avons sélectionné 872 enfants de manière aléatoire et déterminé la fréquence du pica. Nous avons choisi des élèves en bonne santé du même âge, sexe et de la même classe que nos cas afin de servir de groupe témoin. Les cas et les témoins ont été examinés pour détecter une anémie ferriprive. Parmi les 57 élèves $(6,7 \%)$ souffrant de pica, il n'existait pas de lien significatif avec le sexe $(p>0,05)$. Les types les plus connus de pica étaient la géophagie $(62,3 \%)$ et l'ingestion de papier $(31,2 \%)$. La fréquence de l'anémie parmi les cas était plus élevée que chez les témoins, mais la différence n'était pas statistiquement significative. Le ratio de la capacité de fixation du fer sérique/fer total, inférieur ou égal à 0,15 , ne différait pas significativement entre les deux groupes. Nous n'avons trouvé aucune association entre le pica et l'anémie et/ou les carences en fer $(p>0,05)$.

'Zanjan Metabolic Disease Research Centre; 'Zanjan University of Medical Sciences, Zanjan, Islamic Republic of Iran (Correpondence to: Parisa Khoshnevisasl: khoshnevis@zums.ac.ir). ${ }^{3}$ NODET High School, Zanjan, Islamic Republic of Iran.

Received: 22/03/16; accepted: 11/07/16 


\section{Introduction}

Pica is defined as the compulsive eating of non-food material persisting for more than 1 month (1). There are many substances considered as pica such as soil, ice, plaster, cinder, etc. This may vary by ethnicity, culture, race or geographic region (2).

There are several theories to explain pica; one is hunger (3), but given that patients usually consume small quantities of non-food substances between meals, this theory is not fully supported (4). The protection theory maintains that pica is a defensive practice that protects the gastrointestinal tract from absorbing pathogens and chemical substances. Although clay is an effective substance for this (3), more studies are needed to determine this relationship. A protective response to psychological stress is another theory proposed to explain pica (3). The American Psychological Association believes that pica is a psychopathology that needs therapeutic interventions. Some studies show that pica is usually associated with a number of psychological disorders (4).

Another theory for pica is micronutrient deficiency, e.g. iron, zinc, selenium and calcium. There have been many studies on the validity of this hypothesis $(1,3,5)$. According to this theory, the patients' taste towards the deficient material changes (3). Furthermore, it seems that culture plays a major role in some societies (6). For instance clay is used for fertility and childbearing in Turkey, Africa and Australia (7). Pica may have consequences like gastrointestinal disturbances; lead, mercury or arsenic intoxication; parasitic infestation; or potassium abnormalities (8). The frequency of pica varies from place to place, however, it appears to be more common in children, women, black people, people residing in rural areas and pregnant women (9). Its frequency in the United States of America ranges from $4 \%$ among men to $68 \%$ in pregnant women and $18.5 \%$ in children (10).

Despite the widespread prevalence of pica and its association with multiple health issues, little is known about its causes and consequences. Many researchers have studied the relationship between pica and iron deficiency (11-14); nevertheless, the etiology is still a matter of debate. The frequency of pica and its related factors have not yet been studied in the northwestern regions of Iran such as the city of Zanjan. The aim of this study was to determine the frequency of pica and its relationship with iron deficiency in children in Zanjan.

\section{Methods}

This case-control study was conducted on students aged $6-15$ years in Zanjan in 2012. We selected 872 children from Zanjan elementary schools: 580 girls (66.5\%) and 292 boys (33.5 $\%)$ were randomly selected from a total of 13529 students ( 8228 boys, 5301 girls) by multistage probability sampling. The sampling was carried out in 3 steps. The total number of students in grades 1-5 of elementary schools was determined. The proportion of children in each class was calculated. Assuming that each class has 40 students we determined the number of classes in each age group and based on the percentage of the total specimens, the number of clusters was assigned. We selected 32 clusters (40 students in each class) by simple randomization. The sample size was calculated using the formula: $n=z^{2} \times \mathrm{p} \times \mathrm{q} / d^{2}$, where: $\mathrm{p}=$ prevalence, $d=0.005, z=1.96, \mathrm{q}=$ $1-$ p. Sample size was calculated at 860 .

For the control group we randomly choose students who did not have pica of the same age and sex and from the same class as our cases.

We distributed about 1200 questionnaire and 872 were filled in completely by the parents. As participation was voluntary, we did not record reasons for non-participation. Parents gave written informed consent and completed a questionnaire about their children's pica. After collecting the completed questionnaires, the picapositive students (according to parents) were selected as the case group and a student of the same sex and age in the same class was chosen randomly as control group. We considered about 10 more students in control group. From 872 students only 57 students had pica according to the questionnaires but only 45 students accepted to participate. The control group was 65 students but only 45 accepted to do blood tests.

Both the cases and controls were examined by the researchers and their probable signs and symptoms were recorded. Blood samples were collected and tested for haemoglobin, haematocrit, serum iron and total iron binding capacity. Anaemia was defined as haemoglobin level $\leq 11 / \mathrm{dL}$ and iron deficiency as serum iron to total iron binding capacity ratio $\leq 15 \%(15-17)$.

Discrete variables are expressed as counts (\%) and compared using the chi-squared test. Statistical analysis was performed by independent $t$-test and Pearson correlation using SPSS 16.0. Differences were considered statistically significant at $P$-value $<0.05$.

The ethics committee at Zanjan University of Medical Sciences approved this study.

\section{Results}

A total of 872 students participated in this study, 580 girls (66.5\%) and 292 boys (33.5\%). The characteristics of the participants are shown in Table 1 . The children were divided into 3 age groups (6-9 years, $>9-11$ years and $>11$ years) with mean age 9.40 (standard deviation 2.89 ) years. Fifty seven students (6.7\%) had pica, 36 (63.2\%) girls and 21 (36.8\%) boys (Table 1). 


\begin{tabular}{|c|c|c|c|c|}
\hline $\begin{array}{l}\text { Table 1 Demogr } \\
\text { Zanjan, 2012 }\end{array}$ & chool & ren (c & d con & groups \\
\hline Characteristic & & & Case & h) pica \\
\hline & No. & $\%$ & No. & $\%$ \\
\hline $\operatorname{Sex}^{a}$ & & & & \\
\hline Male & 292 & 33.5 & 21 & 7.2 \\
\hline Female & 580 & 66.5 & 36 & 6.2 \\
\hline Age (years) ${ }^{a}$ & & & & \\
\hline $6-9$ & 401 & 45.9 & 16 & 35.5 \\
\hline$>9-11$ & 425 & 48.9 & 24 & 53.4 \\
\hline$>11$ & 46 & 5.2 & 5 & 11.1 \\
\hline
\end{tabular}

* Only 45 participants agreed to the blood testing.

${ }^{a}$ Relationship between pica and sex and pica and age not significant $(P>0.05)$.

We did not find a significant relationship between sex and pica $(P>0.05)$.

The reported types of pica were soil in 33 children (3.8\%), paper in 17 (1.94\%), hair in $10(1.14 \%)$, plaster in $5(0.57 \%)$, cotton thread in $5(0.57 \%)$, plastic materials in $5(0.57 \%)$, cinder in $1(0.11 \%)$ and stone in $1(0.11 \%)$. Pica of paint was not found in our cases. The most common type of pica was soil (62.3\% of the cases) followed by paper (31.2\% of the cases).

Only 45 of the 57 children in the case group, i.e. those with pica, agreed to have blood tests and continued the study ( 30 girls and 15 boys); each of these children was randomly matched with another student in their class who did not have pica of the same sex and age as a control group. The proportion of children with pica increased with age, but there was no significant relationship between pica and age $(P$ $>0.05$ ).

The most frequent symptom reported in both the pica case group who agreed to have blood tests and the control group was irritability. Other frequent symptoms included: weakness, paleness and loss of appetite. We did not find any statistically significant difference between the 2 groups in symptoms reported $(P>0.05)$.

The laboratory results for the blood testing are shown in Table 2. The frequency of anaemia in cases was greater

\begin{tabular}{|c|c|c|c|c|c|}
\hline \multirow[t]{2}{*}{ Variable } & \multicolumn{2}{|c|}{$\begin{array}{c}\text { Cases } \\
(n=45)\end{array}$} & \multicolumn{2}{|c|}{$\begin{array}{l}\text { Controls } \\
(n=45)\end{array}$} & \multirow[t]{2}{*}{$P$-value } \\
\hline & No. & $\%$ & No. & $\%$ & \\
\hline $\mathrm{Hb} \leq 11 \mathrm{~g} / \mathrm{dL}$ & 6 & 13.3 & 2 & 4.4 & \multirow[t]{2}{*}{$>0.05$} \\
\hline $\mathrm{Hb}>11 \mathrm{~g} / \mathrm{dL}$ & 39 & 86.7 & 43 & 95.6 & \\
\hline $\mathrm{HCT} \leq 34 \%$ & 8 & 17.7 & 3 & 6.6 & \multirow[t]{2}{*}{$>0.05$} \\
\hline HCT > 34\% & 37 & 82.3 & 42 & 93.4 & \\
\hline $\mathrm{SI} \leq 50 \mu \mathrm{g} / \mathrm{dL}$ & 3 & 6.6 & 2 & 4.4 & \multirow[t]{2}{*}{$>0.05$} \\
\hline $\mathrm{SI}>50 \mu \mathrm{g} / \mathrm{dL}$ & 42 & 93.4 & 43 & 95.6 & \\
\hline $\mathrm{TIBC} \geq 400 \mu \mathrm{g} / \mathrm{dL}$ & 5 & 11.1 & 1 & 2.2 & \multirow[t]{2}{*}{$>0.05$} \\
\hline $\mathrm{TIBC}<400 \mu \mathrm{g} / \mathrm{dL}$ & 40 & 88.9 & 44 & 97.8 & \\
\hline $\mathrm{SI} / \mathrm{TIBC} \leq 0.15$ & 7 & 15.5 & 8 & 16.7 & \multirow[t]{2}{*}{$>0.05$} \\
\hline $\mathrm{SI} / \mathrm{TIBC}>0.15$ & 38 & 84.5 & 37 & 82.3 & \\
\hline
\end{tabular}

$H b=$ haemoglobin, $H C T=$ haematocrit, $S I=$ serum iron, $T I B C=$ total iron binding capacity .

than in the controls although the difference was not statistically significant. There were 3 cases and 2 controls with serum iron $<50 \mu \mathrm{g} / \mathrm{dL}$ and 5 cases and 1 control with serum total iron binding capacity greater than the expected $400 \mu \mathrm{g} / \mathrm{dL}$, but the serum iron:total iron binding capacity ratio $\leq 0.15$ did not differ significantly between the 2 groups.

\section{Discussion}

In this study from Zanjan, northwestern Islamic Republic of Iran, the frequency of pica in 872 students was $6.7 \%$. The type and prevalence of pica may depend on cultural and ethnic factors (18). In a study on children in Egypt, the prevalence of pica was $7.2 \%$, which is similar to our study (19). Our result is in contrast with a report from Madagascar with 53\% geophagy and $85 \%$ amylophagy. In the observed population pica was not regarded as stigmatized culture, rather a divergent behaviour (20). In studies from the United States of America the prevalence of pica in children ranged between $10.0 \%$ and $18.5 \%(7,10)$. The differences may be explained by the distinct definitions of pica and the parents' unwillingness to declare their child's behaviour abnormal.

As in other studies, the most common type of pica in this study was geophagia (62.3\%). In a study of Zambian children, $74.4 \%$ practiced some form of geophagia (21). In a study in Egypt, clay (43.1\%) and dust (25.9\%) were the most common type of pica (19).

We did not find a significant association between sex and pica. This is concurrent with the findings of Ivascu et al. (21) in a study on patients with sickle cell disease but disagrees with the findings of Nchito et al. which showed a significant incidence of pica in girls in their study from Zambia (22). 
We did not find any association between pica and anaemia and/or iron deficiency $(P>0.05)$. These findings differ from those of some other studies $(3,19,23,24)$. But at least 2 double blind controlled studies did not find any relationship between iron therapy and pica behaviour (10). This is probably because pica is more a cultural behaviour than a result of iron deficiency. On the other hand, some other studies have shown that pica was common in patients with sickle cell anaemia; these patients usually have high iron levels $(22,25)$. It should be taken into account that pica may also be seen in zinc or other micronutrient deficiency.

A limitation of this study was not measuring the concentration of other micronutrients such as zinc, calcium and selenium.
Acknowledgements

We would like to thank all the children and their families for their participation in this study.

Funding: This study was based on a thesis for a medical degree and was funded by the Research Department of Zanjan University of Medical Sciences. Competing interests: None declared.

\section{References}

1. Bay A, Dogan M, Bulan K, Kaba S, Demir N, Öner AF. A study on the effects of pica and iron-deficiency anemia on oxidative stress, antioxidant capacity and trace elements. Hum Exp Toxicol. 2013;32(9) ):895-903. PMID:23444335

2. Barton JC, Barton JCl, Bertoli LF. Pica associated with iron deficiency or depletion: clinical and laboratory correlates in 262 non-pregnant adult outpatients. BMC Blood Disord 2010;10:9. PMID:21176208

3. Young S L, Wilson MJ, Miller D, Hillier S. Toward a comprehensive approach to the collection and analysis of pica substances, with emphasis on geographical material. PLOS One 2008;3(9):e3147. PMID:18773081

4. Placek CD, Hagen EH. A test of three hypotheses of pica and amylophagy among pregnant women in Tamil Nadu, India. Am J Hum Biol. 2013;25(6):803-13. PMID:24130118

5. Lumish RA, Young SL, Lee S, Cooper EM, Pressman E, O'Brien $\mathrm{KO}$. Pica behavior is prevalent and associated with low iron status in pregnant adolescents. FASEB J. 2013;27:634.11

6. Kawai K, Saathoff E, Antelman G, Msamanga G, Fawzi WW. Geophagy (soil-eating) in relation anaemia and helminth infection among HIV-infected pregnant women in Tanzania. Am J Trop Med Hyg. 2009;80(1):36-43. PMID:19141837

7. Blinder, Barton J, Blinder BJ, Salama C. An update on pica: prevalence, contributing causes, and treatment. Psychiatric Times. 2008;25(6):66-70.

8. Mishori R, McHale. Pica: an age-old eating disorder that's often missed. J Fam Pract. 2014 Jul;63(7):E1-4. PMID:25198212

9. Mathee A, Kootbodien T, Mahuma T, Nkomo P, Naik I. A crosssectional analytical study of geophagia practices and blood metal concentrations in pregnant women in Johannesburg, South Africa. S Afr Med J. 2014;104(8):568-73. PMID:25213850

10. Miao D, Sera L, Young CD, Golden A. Meta-analysis of pica and micronutrient status. Am J Hum Biol. 2015;27:84-93. PMID:25156147

11. Nafil H, Tazi I, Mahmal L. Prevalence of pica in iron deficiency anemia in Marrakech (Morocco). Med Sante Trop. 2015;24 [Epub ahead of print] [in French]. PMID:26103958

12. Rabel A, Leitman SF, Miller JL. Ask about ice, then consider iron. J Am Assoc Nurse Pract. 2015;5 [Epub ahead of print]. PMID:25943566

13. Uchida T, Kawati Y. Pagophagia in iron deficiency anemia. Rinsho Ketsueki. 2014;55(4):436-9. PMID:24850454
14. Reilly C, Henry J. Geophagia: why do humans consume soil? Nutr Bull. 2000;25:141-4.

15. Kliegman RM, Stanton BF, St Geme JW, Schor NF, Behrman RE. Nelson textbook of pediatrics, 19th ed. Philadelphia: WB Saunders Company; 2011:2017.

16. Oski FA, Brugnara C, Nathan DG. A diagnostic approach to the anemic patients. In: Nathan DG, Orkin SH, eds. Nathan and Oski's hematology of infancy and childhood, 7th ed. Philadelphia: WB Saunders Company; 2008:Appendix 11.

17. Ghasemi F, Valizadeh F, Taee N. Iron-deficiency anemia in children with febrile seizure: a case-control study. Iran J Child Neurol. 2014 Spring;8(2):38-44. PMC4058064

18. Kettaneh A, Eclache V, Fain O, Sontag C, Uzan M, Carbillon $\mathrm{L}$, et al. Pica and food craving in patients with iron-deficiency anemia: a case- control study in France. Am J Med. 2005;118(2):185-8. PMID:15694906

19. El Nemer FM, Alian DM, Salah Eldin M, Moustafa Khalil $\mathrm{H}$. Prevalence of pica among children attending pediatrics clinic at El-Menoufiya University Hospital. Am J BioScience. 2014;2(4):147-52.

20. Golden CD, Rasolofoniaina BJR, Benjamin R, Young SL. Pica and amylophagy are common among Malagasy men, women and children. PLoS ONE 2012;7(10):e47129. PMID:23082143

21. Ivascu NS, Sarnaik S, McCrae J, Whitten-Shurney W, Thomas $\mathrm{R}$, et al. Characterization of pica prevalence among patients with sickle cell disease. Arch Pediatr Adolesc Med. 2001;155(11):1243-47. PMID: 11695934.

22. Nchito M, Geissler PW, Mubila L, Friis H, Olsen A. Effects of iron and multimicronutrient supplementation on geophagy: a two-by-two factorial study among Zambian school children in Lusaka. Trans R Soc Trop Med Hyg. 2004;98(4):218-27. PMID:15049460

23. Gupta N, Sood S. The serum level of iron, zinc, calcium and selenium in children with pica. Int J Basic \& Applied Physiology. 2014;3(1):151-15.

24. Shruti S, Bhatia MS, Rusia U, Rusia A. Iron profile estimation in children of behavioural disorders. Delhi Psychiatry J. 2010;13(2):339-40

25. O'Callaghan ET, Gold JI. Pica in children with sickle cell disease: two case reports. J Paediatric Nursing. 2012;27(6):e65e70. PMID:22917881 